Apidologie, 1988, 19 (4), 377-386

\title{
ALLOZYME VARIABILITY IN GREEK HONEYBEES (APIS MELLIFERA L.) ${ }^{1}$
}

\author{
Guido BADINO *, Giovanna CELEBRANO *, Aulo MANINO **, Michael D. IFANTIDIS *** \\ * Dipartimento di Biologia Animale. \\ Via Accademia Albertina, 17, I 10123 Torino (Italy) \\ ** Istituto di Entomologia agraria e Apicoltura. \\ Via P. Giuria, 15, I 10126 Torino (Italy) \\ *** Aristotle University, School of Agriculture, Institut of Apiculture and Sericulture. \\ GR 54006 Thessaloniki (Greece)
}

\section{SUMMARY}

Greek honeybees were characterized electrophoretically at 15 loci. Genetic variability at $M d h-1$ and Est loci differentiates among the populations of Isle of Kriti, Peloponnesus and part of continental Greece, and northern Greece, where a transition zone to Carniolan honeybees was detected.

\section{INTRODUCTION}

The taxonomic status of Greek honeybees is not yet thoroughly defined at the subspecific level. Kiesenwetrer (1860) first recognized that they were distinct among the Eastern Mediterranean honeybees and named them Apis mellifica meda var. cecropia. On the basis of morphometric investigations, IfANTIDIS (1979a and 1979b) and RUTTNER et al. (1978) considered the honeybee populations from Peloponnesus and continental Greece to be $A$. mellifera cecropia Kies. RutTner (1980) described those from the Isle of Kriti (Crete) as $A$. $m$. adami Rutt. and subsequently (1988) he established the new PontoMediterranean subspecies $A$. m. macedonica Rutt., which inhabits also Northern Greece. According to RutTNER (1988), A. m. adami shows marked morphological similarities to Near East subspecies, while $A$. m. cecropia and A. m. macedonica appear closely related to the Carniolan bee $(A$. m. carnica Poll.) and also to the Italian bee, A.m. ligustica Spin.

1. This work was supported by a $60 \%$ grant of the Italian Ministero della Pubblica Istruzione.

G. Badino and G. Celebrano dedicate this paper to Prof. Valdo Mazzi, neuroendocrinologist of the Turin University, in his 70th birthday. 
This paper aims to compare enzyme polymorphisms of the Greek honeybees to those already studied in other subspecies from the Eastern Mediterranean area (BAdino et al., 1984 and 1985; Cornuet, 1983 ; ShePPARD \& McPhERon, 1986).

\section{MATERIALS AND METHODS}

On the basis of previous morphometric investigations (IFANTIDIS, 1979 a,b), we selected 23 stationary or migratory apiaries throughout Greece (Tab. I), making sure that 1) colonies were native and no foreign queen had been introduced 2) genetic influence from other apiaries was minimal : the stationary apiaries were rather isolated and the few migratory ones were moved only when no swarming occurred. The number of colonies per apiary ranged from 20 to 200 . A random sample of about 100 live worker bees was collected from each apiary in June and July, 1986 and 1987, and sent to the Torino laboratory, where it was frozen at $-20^{\circ} \mathrm{C}$ until analysis within two weeks. We examined 9 enzymes, encoded by 15 putative loci : MDH (malate dehydrogenase), ME (malic enzyme), PGM (phosphoglucomutase), PGI (phosphoglucose isomerase), G6PDH (glucose-6-phosphate dehydrogenase), IDH (isocitrate dehydrogenase), LDH (lactate dehydrogenase), EST (esterase), and HK (hexokinase). The number of analyzed individuals was the same for all the enzyme systems and is reported in table II. Techniques of tissue extract preparation and electrophoresis on cellulose acetate strips were as described by BaDino et al. (1982 and 1984). The hexokinase locus was studied using a Tris-Citrate $0.05 \mathrm{M}$ electrode buffer at 8.5 $\mathrm{pH}$. After migration, activity bands were stained using standard histochemical methods.

\section{RESULTS}

Only two loci, Mdh-1 (the most anodally migrating locus) and Est, were polymorphic in Greek honeybees. $M d h-3$, which migrated cathodally, showed some variability, possibly exhibiting two alleles, but was not consistently scorable and is excluded from the analysis. The other putative loci exhibited invariant banding patterns.

\section{Mdh-1 locus}

In Greek bee populations, the $M d h-1$ polymorphism consisted of two alleles, named Mdh-1-F and Mdh-1-S in order of decreasing electrophoretic mobility (Fig. 1). On the basis of their relative mobility, these alleles correspond to $M d h-100$ and $M d h-65$, respectively, of Sheppard and Berlocher (1985).

The frequency distributions of $M d h-1-S$ and $M d h-1-F$ are shown in Table 1 and figure 2. These two alleles have been reported in A.m. ligustica (Badino et al., 1983a, 1983b, 1984 ; Cornuet, 1983 ; Sheppard and Berlocher, 1985) and in $A$. m. carnica (BADino et al., 1983b, 1984 ; ShePPARd and McPheron, 1986). 


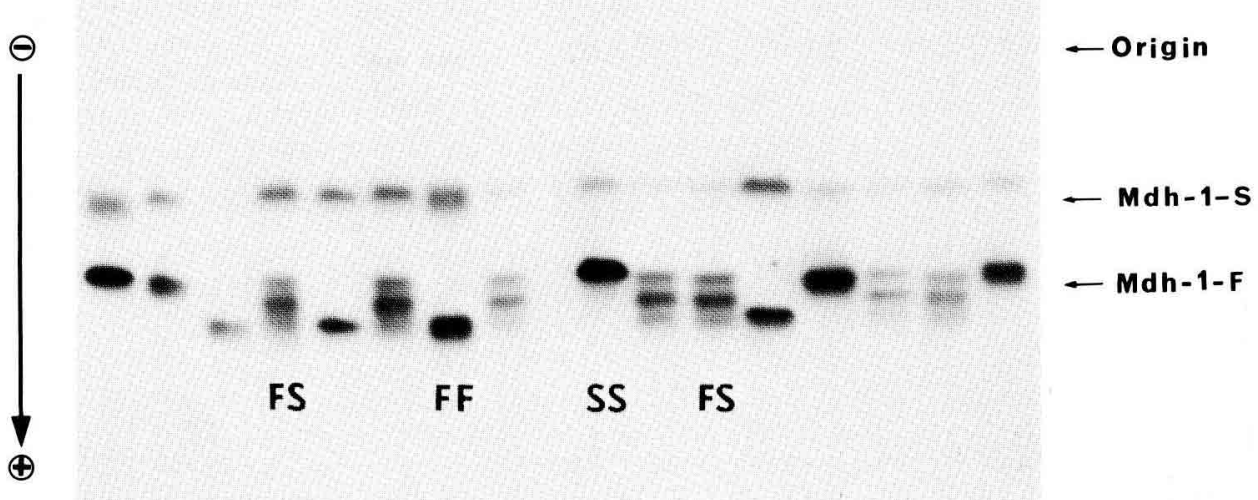

Fig. 1. - Anodal MDH electrophoretic partern of Greek honeybees.

$M d h-1$ was fixed for $M d h-1-F$ in the populations we studied from the Isle of Kriti. On mainland, $M d h-1-F$ frequencies gradually decreased, going north through Peloponnesus up to Macedonia, but remained high in the eastern region near the Turkish border. The lowest values were 0.286 and 0.475 at Kilkis and Drama, respectively, while all the other samples had $M d h-1-F$ allele frequencies over 0.5 .

In Peloponnesus and continental Greece the geographical distribution of $M d h-1-F$ frequencies does not follow a straight latitudinal cline, as was observed in Italy (Badino et al., 1984). Mdh-1 allele frequencies are not significantly correlated with latitude in Greece $\left(F_{1,17}=2.309 ; \mathrm{P}=0.144\right)$.

Three samples (6, 7, and 19) displayed a significant excess of heterozygotes compared to Hardy-Weinberg expectations. All other samples were in accordance with Hardy-Weinberg's equilibrium.

\section{Est locus}

The Est locus exhibited 3 alleles, Est-F, Est-M, Est-S, previously reported in A.m. ligustica (BADINo et al., 1984). These alleles almost certainly correspond to Est-130, Est-100 and Est-70, respectively, found by SHEPPARD and McPheron (1986) in Czechoslovakian honeybees of uncertain racial affinity.

Est-M was the most frequent allele in Greece : it appeared fixed in 19 of 23 samples (Table 1). This allele is also commonly fixed in honeybee populations from peninsular Italy, Austria, and Rumania (BADINo et al., 1984), as 
TABL. 1. - Mdh-1 and Est allele frequency distributions in Greece, obtained from 23 apiaries

\begin{tabular}{|c|c|c|c|c|c|c|c|c|}
\hline \multirow[t]{2}{*}{ Localities } & \multirow[t]{2}{*}{$\mathrm{N}$} & \multicolumn{2}{|c|}{$\begin{array}{c}\text { Mdh-1 locus } \\
\text { Allele } \\
\text { frequencies }\end{array}$} & \multirow{2}{*}{$\mathrm{H}_{\text {obs. }}$} & \multirow{2}{*}{$\mathbf{H}_{\text {exp. }}$} & \multicolumn{3}{|c|}{$\begin{array}{l}\text { Est locus } \\
\text { Allele frequencies }\end{array}$} \\
\hline & & F & $\mathrm{S}$ & & & $\mathrm{F}$ & $\mathbf{M}$ & $\mathrm{S}$ \\
\hline \multicolumn{9}{|l|}{ Mainland Greece } \\
\hline 1. Drama & 60 & 0.475 & 0.525 & 0.416 & 0.499 & - & 1.000 & - \\
\hline 2. Egiros & 21 & 0.857 & 0.143 & 0.286 & 0.245 & - & 1.000 & - \\
\hline 3. Serres & 49 & 0.622 & 0.378 & 0.551 & 0.470 & - & 1.000 & - \\
\hline 4. Ferre & 15 & 0.833 & 0.167 & 0.333 & 0.277 & - & 1.000 & - \\
\hline 5. Sappe & 21 & 0.762 & 0.238 & 0.476 & 0.363 & - & 1.000 & - \\
\hline 6. Kilkis & 20 & 0.286 & 0.714 & 0.600 & 0.480 & - & 1.000 & - \\
\hline 7. Pella & 49 & 0.622 & 0.377 & 0.673 & 0.470 & - & 0.980 & 0.020 \\
\hline 8. Thessaloniki & 53 & 0.641 & 0.359 & 0.566 & 0.459 & - & 1.000 & - \\
\hline 9. Chalkidiki & 49 & 0.602 & 0.378 & 0.592 & 0.479 & - & 1.000 & - \\
\hline 10. Grevena & 57 & 0.759 & 0.240 & 0.351 & 0.370 & - & 1.000 & - \\
\hline 11. Elassona & 86 & 0.686 & 0.314 & 0.488 & 0.430 & - & 0.977 & 0.023 \\
\hline 12. Larissa & 60 & 0.617 & 0.383 & 0.400 & 0.488 & - & 1.000 & - \\
\hline 13. Trikala & 86 & 0.843 & 0.157 & 0.244 & 0.265 & - & 1.000 & - \\
\hline 14. Arta & 45 & 0.633 & 0.367 & 0.555 & 0.464 & - & 1.000 & - \\
\hline 15. Pelasgia & 19 & 0.789 & 0.211 & 0.211 & 0.332 & - & 1.000 & - \\
\hline 16. Thermopiles & 65 & 0.769 & 0.231 & 0.369 & 0.355 & - & 0.985 & 0.015 \\
\hline 17. Korinthos & 55 & 0.891 & 0.109 & 0.182 & 0.194 & - & 1.000 & - \\
\hline 18. Arkadia & 16 & 0.812 & 0.188 & 0.250 & 0.300 & 0.031 & 0.969 & - \\
\hline 19. Kalamata & 38 & 0.750 & 0.250 & 0.500 & 0.375 & - & 1.000 & - \\
\hline \multicolumn{9}{|l|}{ Kriti Island } \\
\hline 20. Chania & 59 & 1.000 & - & - & - & - & 1.000 & - \\
\hline 21. Retimno & 35 & 1.000 & - & - & - & - & 1.000 & - \\
\hline 22. Iraklion & 60 & 1.000 & - & - & - & - & 1.000 & - \\
\hline 23. Ierapetra & 27 & 1.000 & - & - & - & - & 1.000 & - \\
\hline
\end{tabular}

$\mathrm{N}=$ number of adult worker bees electrophoresed from each apiary.

$\mathbf{H}_{\mathrm{obs}}=$ observed portion of heterozygote individuals per apiary.

$\mathrm{H}_{\text {exp. }}=$ portion of heterozygote individual expected according to Hardy-Weinberg equilibrium.

well as in $A$. m. mellifera L. (BAdino et al., 1984 ; ShePpard and Berlocher, 1984). Est-S was present only in three populations from northern Greece at very low frequency. This allele is prevailing in $A$. $m$. sicula Mont. (Badino $e t$ al., 1985) and was also found by Sheppard and McPheron (1986) in Czechoslovakian colonies headed by A.m. carnica queens. Est-F, also rare, was found only in Arkadia (sample 18). This allele has been reported in peninsular Italy, Austria and Czechoslovakia (Badino et al., 1984 ; ShePPARD and Berlocher, 1985 ; ShepPard and McPheron, 1986). 


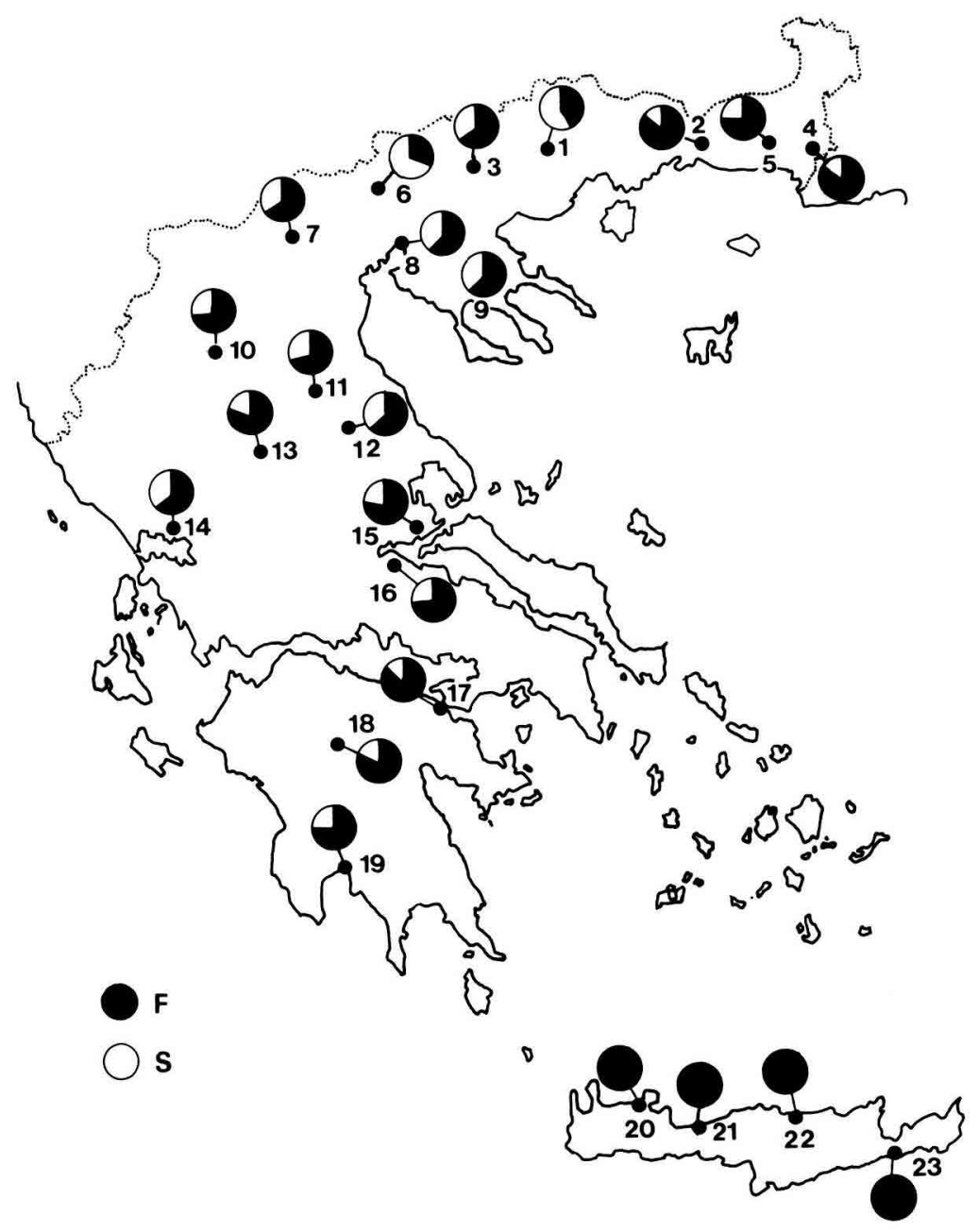

Fig. 2. - Geographic distribution of the Mdh-1 allele frequencies in Greek honeybee populations. Localities are numbered as in table 1.

\section{DISCUSSION}

The Mdh-1-S allele, common in both Italian and Carniolan honeybees (BADINo et al., 1984), was found throughout mainland Greece. Its frequencies in the continental Greece colonies are normally quite low, varying between 0.143 and 0.383 . Only two apiaries from Northern Greece (Drama and Kilkis) 
exceeded this range, showing frequencies of 0.575 and 0.714 respectively : such figures are within the frequency range observed by BADINo et al. (1984) in Carniolan honeybee populations from Austria and Rumania, i.e. 0.507-0.885, and from Czechoslovakia (Sheppard \& McPheron, 1986). Moreover, we found an area near Drama and Kilkis, comprising the localities of Serres, Pella, Thessaloniki, and the Chalkidiki peninsula, where both $M d h-1-S$ frequencies and observed heterozygosities at $M d h-1$ locus were higher than elsewhere. The distribution area of $A$. m. macedonica shown by RUTTNER (1988) for northern Greece nearly overlaps this apparent transition zone to A.m. carnica (Fig. 3).

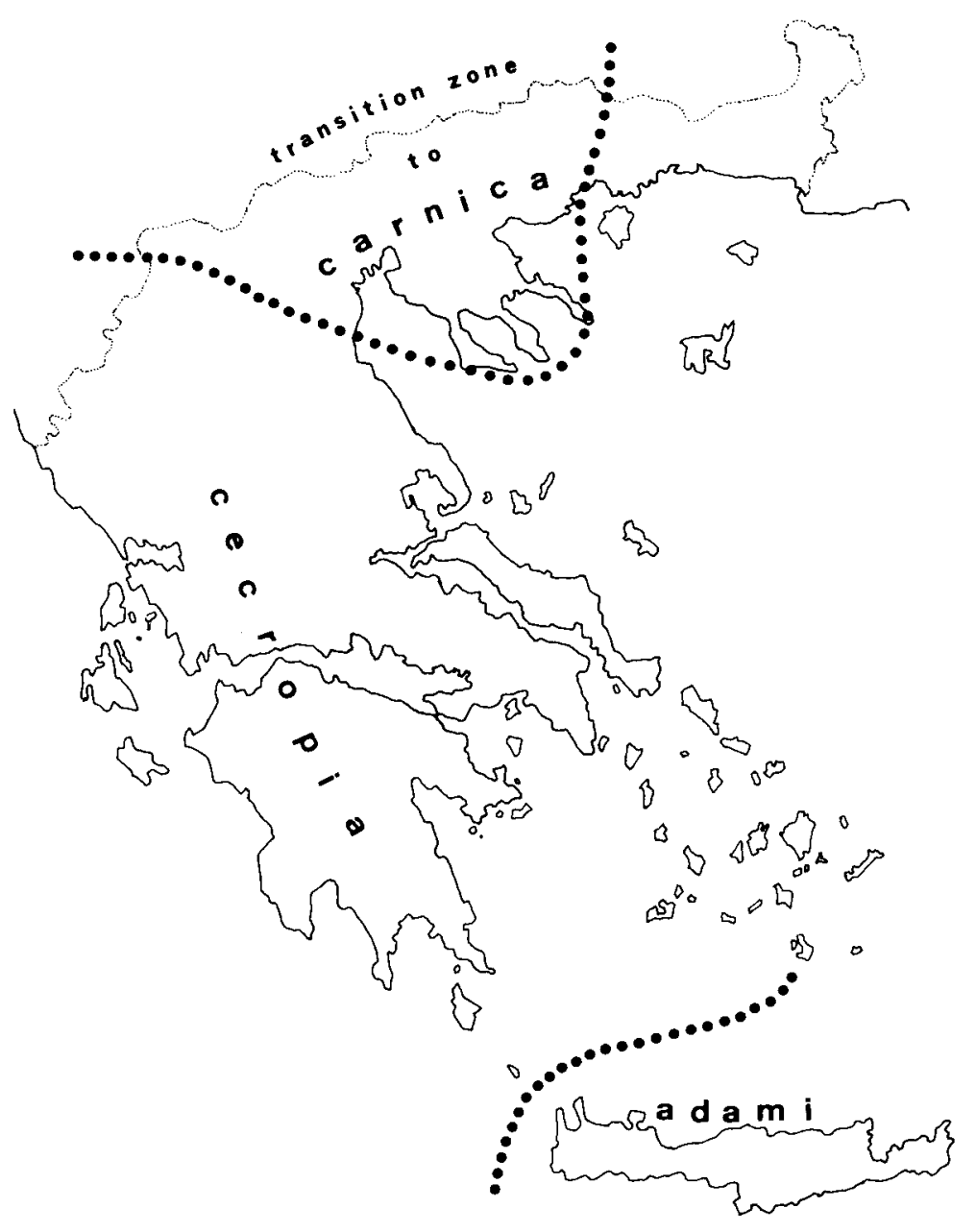

FIG. 3. - Geographic distribution of honeybee races in Greece. 
In general, honeybees from other parts of continental Greece and from Peloponnesus can be distinguished on the basis of Mdh-1-S allele frequencies (lower than 0.4). Therefore, this may represent electrophoretic evidence to consider these honeybees as a separate subspecies, A.m. cecropia.

In native honeybees from the Isle of Kriti, we never found the $M d h-1-S$ allele nor the rare alleles at the Est locus that appeared in some mainland colonies. Evidently, the sea is a geographical barrier efficient enough to reduce gene flow between island and mainland Greece, so that some genetic differentiation - due to founder effect or genetic drift and, perhaps, selective pressure - can be maintained. The consequent fixation at Mdh-1 and Est loci allows us to separate the Kriti honeybees from mainland populations using electrophoresis. This supports the work of RUTTNER (1980), who described them as a separate subspecies, A.m. adami.

Nei's genetic distances calculated between the populations of A.m. cecropia, A.m. carnica and A.m. adami, on the basis of all 15 enzyme loci were very low. They ranged from 0.004 to 0.018 between mainland Greek honeybees and Carniolan bees, and from 0.001 to 0.010 when comparing mainland Greek with Kriti ones. These figures are smaller than those resulting from the comparison between A.m. ligustica and A.m. mellifera $(\mathrm{D}=0.059$, calculated on the basis of data from BADINo et al., 1984). Such very low genetic differences between subspecies is probably due to the limited isozyme polymorphisms of $A$. mellifera. The close genetic correlation between Greek and Carniolan honeybees could indicate a common phylogenetic origin for the subspecies group of the Central Mediterranean and South-East Europe (RuTTNER, 1988), but could also be the effect of extensive importations of Italian and Carnolian queens into Greece. In the absence of diagnostic alleles, however, the reduced genetic differentiation between the races due to importation cannot be easily shown using electrophoresis.

Received for publication in December 1987. Accepted for publication in June 1988.

\section{ACKNOWLEDGEMENT}

The authors wish to thank Dr. Dimitrios Moissidis, who contributed to electrophoretic analysis. 


\section{RÉSUMÉ \\ VARIABILITÉ GENÉTIQUE AU NIVEAU DES ALLOENZYMES CHEZ LES ABEILLES GRECQUES}

Des échantillons de 15 à 86 abeilles ouvrières ont été prélevés dans 23 ruchers répartis à travers la Grèce et étudiés par les méthodes de révélation des isoenzymes. Neuf systèmes enzymatiques, commandés par 15 locus probables ont été étudiés par électrophorèse (MDH, ME, PGM, PGI, G6PDH, IDH, LDH, EST, HK). Parmi ceux-ci, seuls le $M d h-1$ et l'Est ont présenté un polymorphisme. Pour $M d h-1$ on a trouvé les deux mêmes allèles (Mdh-1-F et $M d h-1-S$ ) que chez A.m. ligustica et A.m. carnica. Les colonies du Péloponèse et d'une partie de la Grèce continentale présentent des fréquences de $M d h-1-S$ inférieures à 0,4 et pourraient représenter le type de la race $A . m$. cecropia. Le spectre électrophorétique de $M d h-1$ permet de discriminer une région du nord de la Grèce comme étant soit une zone de transition d'A.m. carnica, soit la partie occidentale de l'aire de distribution d'A.m. macedonica. Les fréquences alléliques d'Est des abeilles grecques sont semblables à celles relevées chez les abeilles carnoliennes et italiennes. Malgré les importations récentes provenant de la Grèce continentale, les abeilles crétoises indigènes se caractérisent par la fixation des allèles les plus communs d'A.m. cecropia aux deux locus $M d h-l$ et $E s t$ : cela confirme l'opinion selon laquelle ces abeilles appartiennent à une sous-espèce individualisée, A.m. adami.

\section{ZUSAMMENFASSUNG ISOENZYMVARIABILITÄT IN GRIECHISCHEN HONIGBIENEN}

Bienenproben von 15-86 Arbeitsbienen wurden von 23 Bienenständen in Griechenland gesammelt und ihre Isoenzyme untersucht. Neun Enzymsysteme mit vermutlich 15 Loci wurden elektrophoretisch ausgewertet (MDH, ME, PGM, PGI, G6PDH, IDH, LDH, EST und HK). Von diesen erwiesen sich nur $M d h-1$ und Est als polymorph. Bei $M d h-1$ wurden dieselben zwei Allele ( $M d h-1-F$ und $M d h-1-S$ ) wie bej A.m. ligustica und A.m. carnica gefunden. Die Völker vom Peleponnes und von einem Teil des griechischen Kontinents zeigten $M d h-1-S$ Frequenzen von weniger als 0.4 und könnten typische $A . m$. cecropia sein. Darüberhinaus könnte das $M d h-1$ Muster verwendet werden, um die Bienen in Nordgriechenland der Übergangszone zu A.m. carnica oder dem westlichsten Teil von A.m. macedonica zuzuordnen. Die Est-Allel-Frequenzen waren bei den griechischen Honigbienen die gleichen wie bei $A$. $m$. carnica und A.m. ligustica. Trotz rezenter Importe von griechischen Bienen nach Kreta zeigen die kretischen Bienen nur ein Allel an den Mdh-1 und Est-Loci, und zwar das bei A.m. cecropia jeweils häufigste Allel. Dies weist darauf hin, daß diese Bienen tatsächlich einer eigenen Subspecies, A.m. adami, angehören.

\section{REFERENCES}

Badino G., Celebrano G., Manino A., 1982. - Genetic variability of Apis mellifera ligustica Spin. in a marginal area of its geographical distribution. Experientia, 38, 540-541.

Badino G., Celebrano G., Manino A., 1983a. - Population structure and $M d h-l$ locus variation in Apis mellifera ligustica. J. Hered., 74, 443-446.

Badino G., Celebrano G., Manino A., 1983b. - Identificazione di Apis mellifera ligustica Spin. sulla base di sistemi gene-enzima. Boll. Mus. Reg. Sci. Nat. Torino, 1, 451-460.

Badino G., Celebrano G., Manino A., 1984. - Population genetics of Italian honeybee (Apis mellifera ligustica Spin.) and its neighbouring subspecies. Boll. Mus. Reg. Sci. Nat. Torino, 2, 571-584.

Badino G., Celebrano G., Manino A., Longo S., 1985. - Enzyme polymorphism in the Sicilian honeybee. Experientia, 41, 752-754. 
CoRnuet J.M., 1983. - Reproduction, génétique et sélection de l'abeille. Bull. Tech. Apic., 10, 13-36. Ifantidis M., 1979a. - L'abeille grecque, Apis mellifera cecropia. Etude morphologique de l'ouvrière. XXVII Congr. Int. Apic., Athenes, 271-277.

IfaNTIDIS M., 1979b. - Caractères morphologiques des faux bourdons d'Apis mellifera cecropia. XXVII Congr. Int. Apic., Athenes, 278-280.

Kiesenwetter E.A.H. von, 1860. - Über die Bienen des Hymettos. Berlin. entomol. Z., 4, 315-317.

Rutrner F., 1980. - Apis mellifera adami (n.ssp.), die kretische Biene. Apidologie, 11, 385-400.

Rutrner F., 1988. - Biogeography and Taxonomy of Honeybees. Springer-Verlag, Berlin Heidelberg. $284+$ XII pp.

Ruttner F., Tassencourt L., Louveaux J., 1978. - Biometrical-statistical analysis of the geographic variability of Apis mellifera L. Apidologie, 9, 363-381.

Sheppard W.S., Berlocher S.H., 1984. - Enzyme polymorphism in Apis mellifera mellifera from Norway. J. apic. Res., 23, 64-69.

Sheppard W.S., Berlocher S.H., 1985. - New allozyme variability in Italian honeybees. J. Hered., 76, 45-48.

Sheppard W.S., McPheron B.A., 1986. - Genetic variation in honey bees from an area of racial hybridization in Western Czechoslovakia. Apidologie, 17, 21-32. 